\title{
PARENTAL CHILD ABDUCTION CASES: PREVENTION IS BETTER THAN CURE
}

\author{
Frans M Mahlobogwane \\ B Proc, LLB, LLM \\ Senior Lecturer, Department of Jurisprudence \\ University of South Africa (UNISA)
}

\section{SUMMARY}

The past few decades have witnessed an unprecedented growth of child abduction cases that has generated the need for legislative framework governing such cases. This happened, after a period of uncertainty on how the courts should deal with abduction cases, as a result, our South African legislature incorporated the Hague Convention on the Civil Aspects of International Child Abduction Act 72 of $1996 .{ }^{2}$ The Act came into operation on the 01 October 1997, making the Hague Convention applicable in South Africa. This paper will look into the issue of prevention of parental child abduction and whether such prevention will promote the child's best interests in such cases.

\section{$1 \quad$ WHAT IS PARENTAL CHILD ABDUCTION?}

According to Andrea Himel, ${ }^{3}$ parental abduction involves a situation where:

"(a) a parent takes a child before a custody agreement or order is made; (b) a parent, in violation of a custody agreement or order fails to return or give over a child at the end of a legal or agreed-upon visit and the child is away for at least one week; (c) an attempt is made to conceal the taking or the whereabouts of the child and to prevent contact with the child; or, (d) The child is either transported out of the Province, or, there is evidence that the abductor intends to keep the child indefinitely or to permanently affect custodial rights."

Thus, abduction involves cases where a parent has removed a child from the child's ordinary habitual residence without that particular child's consent, or the consent of the person with parental responsibilities who had been caring for the child in that particular resident. ${ }^{4}$ Either parent can remove the

* This article originates from a paper presented at The International Journal of Arts and Sciences (IJAS) conference held at The Joseph B Martin Conference Centre at Harvard Medical School, Boston, Massachusetts, 26-30 May 2014.

Morewitz Domestic Violence and Maternal and Child Health (2004) 47-67.

Hereinafter "the Act".

Himel "Parents Stealing Kids: Part II - Profiling the Parental Abductor" 200818 Can. Fam. L.Q 2472

4 Skelton and Carnelley Family Law in South Africa (2010) 273. 
child from his habitual residence, provided there is mutual consent of the other parent with parental responsibilities, and further that no court order is prohibiting such removal. Removal of a child without appropriate consent will thus invoke the prompt implementation of the Hague Convention procedures.

Under the South African common law, the custodian parent used to be the one who has the right to choose and establish the right of the child in his care. ${ }^{5}$ However, after the introduction of the Guardianship Act 192 of 1993 , ${ }^{6}$ equal and joint guardianship status was conferred on parents of children born within the marriage. ${ }^{7}$ The same Act further prohibited the removal of the child from the Republic, either by one parent or by a third party without the consent of both parents. If consent was refused, the custodial parent had to make an application to the High Court, which granted the custody order for such removal. The court would, however, always regard the best interests ${ }^{8}$ of the child as the paramount consideration in determining whether the child would be allowed to be removed from its habitual residence. ${ }^{9}$

The other party could make an application to vary the custody order, alternatively make an application to recover the child from the country to which the child has been removed. An interdict would also be granted where there is a threat of removal.

The Children's Act, ${ }^{10}$ has, however brought about changes to the Guardianship Act in that both parents now have legal responsibilities in respect of their children whether married or unmarried. ${ }^{11}$ However, those responsibilities will exist only in so far as they comply with the best interest of the child.

\section{WHY DO PARENTS ABDUCT THEIR CHILDREN?}

Parents find a number of reasons for abducting their children from another parent. The parent may abduct because he is fearful of being denied custody, and further that he may not be granted reasonable visitation rights. ${ }^{12}$ The parent may feel wronged by the legal system and the current custodial arrangements. ${ }^{13}$ The abducting parent may also wish to inflict pain

5 Bonthuys "Parental Rights and Responsibilities in the Children's Bill 70D of 2003" 20063 Stell LR 482483.

6 This Act has been repealed by the Children's Act 38 of 2005.

7 Prior to Guardianship Act, mothers had automatic guardianship status, whereas fathers qualified to be guardians by virtue of marriage, prior either to the birth or at any time subsequent to the birth of the child.

8 This concept has been part of South African law since the case of Fletcher $v$ Fletcher.

9 The common problem at the root of legal disputes is that parents who are not allowed to remove the child from its habitual residence by legal means may unfortunately resort to abduction.

1038 of 2005.

11 Acquisition of parental responsibilities and rights is governed by s 18 to 21 of the Act. These rules are however different for both biological mothers, married and unmarried fathers.

12 Starr "Preventing Parental Child Abduction - The Role of the Lawyer in Managing the Risk" 201332 Can. Fam. L.Q 148.

13 Ibid. 
or cause harm to the other parent. ${ }^{14}$ The abducting parent may also believe that they are acting in the best interests of the child, and this can be attributed to the increase in marriages and divorces between bi-national couples who have different cultural, ethnic and religious beliefs. ${ }^{15}$

Although it was initially expected that the Hague Convention would be invoked to deal with cases where the parent who did not have custody, usually the father, would abduct the child, research has shown that most abductions are by the mother of the child. ${ }^{16}$ In most of these cases, the mother would take the child to her home country, immediately after the marriage has irretrievably broken down. ${ }^{17}$

There is no restriction on parents who exercise joint custody when they both decide to move to another country and take their children with them. The difficulty arises when they separate and raise different views about where the children should live. Where one parent has sole custody and the other parent has rights of visitation, the custodial parent is the only one legally vested with authority to make the most important child-rearing decisions. However, the other parent may react by taking the child to another country to prevent the other parent from exercising his or her rights of custody or of access and, on the other hand, to try to obtain custody of the child in a foreign country.

Article 3 of the Hague Convention provides that the removal or retention of the child is unlawful if it is in breach of rights of custody attributed to a person, either jointly or alone, under the law of the state in which the child was habitually a resident immediately before the removal or retention; ${ }^{18}$ and at the time of removal or retention those rights were actually exercised; or would have been exercised but for the removal or retention. ${ }^{19}$ The same Convention does not apply when custody has been abandoned. The Hague Convention applies to both abductions that occur before and after issuance of custody orders, as well as abductions by a joint custodian. ${ }^{20}$ Thus, a custody order is not a prerequisite to invoking the protection afforded by the Hague Convention.

\section{THE CONSEQUENCES OF PARENTAL ABDUCTION ON CHILDREN}

It may be believed that abduction by the parent does not cause harm to the child, unfortunately, this is not true, abducted children suffer from severe anxiety as they are told that the other parent is dead or did not love them. ${ }^{21}$ This may be due to the fact that one of the myriad of motives in parental abductions is due to an act of anger or revenge against the other parent.

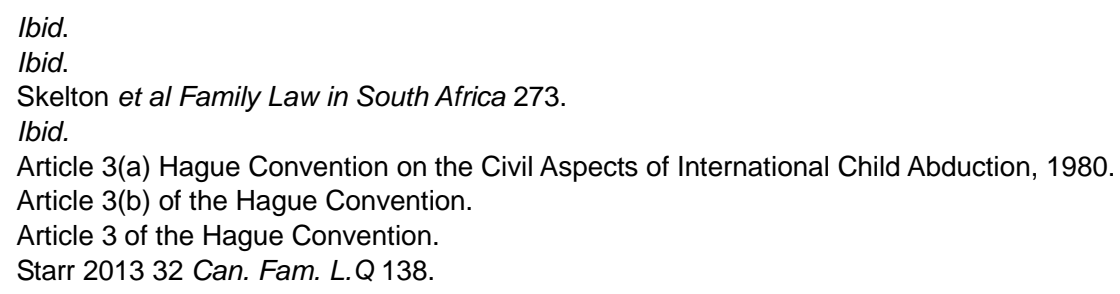


Abducted children are given new identities to avoid detection. In extreme cases, abducted children are often deprived of education and healthcare services to avoid the risk of being tracked through the school or medical records. ${ }^{22}$

The behaviour of abducted children can be difficult for third parties to understand as they are taught to fear those that can offer assistance, such as teachers, police, doctors and counsellors. ${ }^{23}$ These children are living a life on the run; as a result, they are subjected to severe psychological and emotional distress that may torment them for many years to come.

\section{RIGHTS OF CUSTODY AND ACCESS}

Article $27(2)^{24}$ provides that: "the parent(s) or others responsible for the child have the primary
responsibility to secure, within their abilities and financial capacities, the conditions of living necessary for the child's development".

In terms of Article $5,{ }^{25}$ rights of custody and access are defined as;

"For the purpose of this convention - (a) 'rights of custody' shall include rights relating to the care of the person of the child and, in particular, the right to determine the child's place of residence;

(b) 'rights of access' shall include the right to take the child for a limited period of time to a place other than the child's habitual residence."

Therefore, anyone who invokes the Hague Convention must have been exercising custody of the child at the time of the abduction. Persons other than biological parents whose custody rights are violated can invoke the Hague Convention to secure the return of their child, even from a biological parent. A court implementing the Hague Convention is required to determine the court best placed to make a custody determination and not to make a custody determination itself.

Although the Hague Convention does not define the term "parents", there is no suggestion that the concept excludes biological parents merely because they are not married. The provisions of the Hague Convention should, therefore, apply with equal force to the parents of children born out of wedlock.

\section{WHAT IS THE AIM OF THE HAGUE CONVENTION?}

The Hague Convention on the Civil Aspects of International Child Abduction's ${ }^{26}$ preamble and Article 1 state exactly the purpose of the Convention. The preamble provides "To protect children internationally from the harmful effects of their wrongful removal or retention and to establish 
procedures to ensure their prompt return to the state of their habitual residence, as well as to secure protection for rights of access." Article 1's objectives are set out as follows:

a) To secure the prompt return of children wrongfully removed to or retained in any contracting state; and

b) To secure the rights of custody and of access under the law of one Contracting State are effectively respected in the other Contracting States.

Article 11 of the Hague Convention also provides that member states must take measures to combat abduction.

In $\operatorname{Re} D$ (Abduction: Rights of Custody) ${ }^{27}$ Baroness Hale summed the purpose of the Convention as follows:

"The whole object of the Hague Convention is to secure the swift return of children wrongfully removed from their home country, not so only that they can return to the place which is properly their 'home', but also so that any dispute about where they should live in the future can be decided in the courts of their home country, according to the laws of their home country and in accordance with the evidence which will mostly be there rather than in the country to which they have been removed."

The Hague Convention applies only to those countries that have adopted it as "Contracting States". The Hague Convention requires member states to return children abducted from another member state to the country where the child habitually resided in order for that court to determine where and with whom the child should live.

Removal refers to the date of departure, whereas retention refers to the date when permission to take the child abroad ended, either by the terms of an agreement between the parties or by the conduct reflecting an intention not to return the child. The latter applies even if an abductor has obtained an order from the foreign court permitting the child to stay in the foreign country for a while.

A lawful removal for a holiday can become wrongful retention if the parent makes his intentions clear that he does not want to return with the child. The making of court applications to stay in a foreign country will serve as proof that the parent sought to retain the child.

\section{What is "habitual residence"?}

The Hague Convention only applies to international situations involving children who were "habitually resident" in a contracting state immediately prior to any breach of custody or visitation rights. The $\mathrm{Act}^{28}$ and the Hague Convention do not define the term "habitual residence". It is assumed that

27 [2007] 1 FLR 961, see specifically of $R e D$ (Abduction: Rights of Custody) [2006] UKHL 51 par 48.

28 Hague Convention as adopted by the South African legal system. 
the courts should use their own interpretation of the term in the context of the Hague Convention's purpose.

In the USA case of Feder $v$ Evans-Feder, ${ }^{29}$ habitual residence is defined as:

"a child's habitual residence is the place where he or she has been physically present for an amount of time sufficient for acclimatization and which has a 'degree of settled purpose' from the child's perspective."

The Hague Convention articles are premised upon the belief that the court of the child's place of habitual residence immediately before the abduction is best placed to make a determination on the merits and has the most significant interest in resolving the matter.

There are however six possible defences or exceptions to the mandatory return of a child. The parent who opposes the return can raise these defences, upon establishment of the conditions for the return of the child to the country of its habitual residence.

\section{Consent or subsequent acquiescence by the other parent at the child's habitual residence ${ }^{30}$}

The fact that the parent seeking the return of the child at some stage gave permission for the child to move to another country, or made it clear that he or she accepted that the child would be moving to another country, amounts to consent.

In the United States, the court of appeals in Friedrich $v$ Friedrich ${ }^{31}$ sets out a strict and narrow test. The court held that:

\footnotetext{
"Acquiescence under the Convention requires either an act or statement with the requisite formalities such as testimony in a judicial proceeding, a convincing written renunciation of rights or a consistent attitude of acquiescence over a significant period of time."

In the case of Emmett $v$ Perry ${ }^{33}$ Jordan $\mathrm{J}$ stated that:

"[e]ssential components of any relevant acquiescence must include, firstly, an acceptance of the course of conduct of the other party and, secondly, such acceptance must be communicated to the other party. The acquiescence must also be unequivocal".

However, in another case of Cashman v 7 North Golden Gate Mining Co, ${ }^{34}$ Griffiths CJ said that term acquiescence might:
}

"[b]e fairly applied to a man who, seeing an act about to be done to his prejudice, stands by and does not object to it. He may very properly be said to

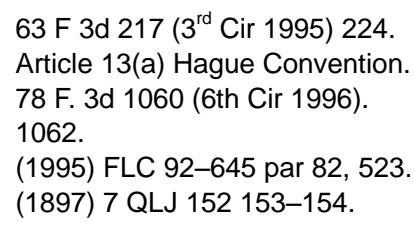


be acquiescing in the act being done ... A man who stands by and sees an act to be done, which will be injurious to himself, and makes no objection, cannot complain of that act as a wrong at all. He never has any right of action, because he stands by and allows an act to be done".

\section{Parent not actually exercising custody rights at the time of an abduction ${ }^{35}$}

The burden to prove that custody rights were not actually exercised at the time of the removal or retention, or that the applicant had consented to or acquiesced in the removal or retention, rests on the person opposing return.

\section{Grave risk of physical or psychological harm or place in an intolerable situation ${ }^{36}$}

Under Article 13(b), the court has discretion not to order the return of a child if there is a grave risk that the return would expose the child to physical harm or otherwise place the child in an intolerable situation.

In the South African case of $W S v L S^{37}$ it was held that the onus of proof rests on the respondent to show a high or grave risk of harm before the return of the child can be granted. The risk has to be more than an ordinary risk in order to come within the provisions of the Hague Convention.

\section{Now settled in its new environment ${ }^{38}$}

Article 12 mandates the courts to return the child if the application is brought within one year of removal. The delay in the proceedings of returning the child back to the country where he is habitually a resident for more than one year after the proceedings have been lodged will result in the court not being bound to return the child. However, the child may still be returned after the lapse of a year, unless it is proven that the child is already settled in that environment, although it is within the court's discretion. The court determining the Hague application may in such circumstances, hear evidence as to whether a return to the country of habitual residence may harm the child. ${ }^{39}$ In this instance, the court may take into account the child's preference if the child is deemed to be of a sufficient maturity to express such a preference. ${ }^{40}$

\section{Objection of the child ${ }^{41}$}

As much as parents and the state have rights, children clearly also possess rights. Article 12 of the Hague Convention on the Rights of the Child ${ }^{42}$

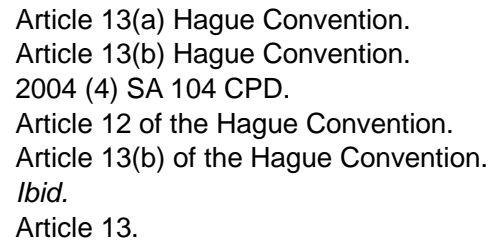


addresses the need for children to have their voices heard, with the assistance of effective legal counsel, in all judicial or administrative matters affecting them.

This article ${ }^{43}$ clearly embodies the principle that a child has a right to express his or her opinion freely and to have that opinion taken into account in any matter or procedure affecting the child. This principle would require an assessment of the child's ability to form an opinion. Thereafter, if the court finds that the child is sufficiently mature, it would be required to give due weightage to that opinion. The child objects to being returned and has attained an age at which considering his or her views are appropriate. ${ }^{44}$

Article 13 directs the courts to take into account the child's views. ${ }^{45}$ Where the child raises an objection, the court might refuse to return the child if it is considered that he is of an age and maturity where his views may be considered. An older child will obviously have more influence on the court's decision than a younger one. Therefore, if a child objects to being returned, and is of such an age and maturity that he is capable of forming his own views, not giving due weight to those views will be inappropriate. ${ }^{46}$

Two important considerations of legal policy underpin the right to be heard. The first relates to recognition of the subject's dignity and sense of worth. ${ }^{47}$ Secondly, there is a pragmatic consideration that the right to be heard is inherently conducive to better administration. Milne $\mathrm{JA}^{48}$ held:

"it satisfies the individual's desire to be heard before he is adversely affected and it provides an opportunity for the repository of the power to acquire information which may be pertinent to the just and proper exercise of the power.'

In the case of Emmett $v$ Perry ${ }^{49}$ Jordan $\mathrm{J}$ found that:

"It would be dangerous and unsatisfactory to place significant weight upon the subsequent development of the children's wishes in the background of one parent having made a unilateral decision in defiance of an existing custody order and with the children being under the sole influence of that component parent who would necessarily be in a position to engage in active or passive manipulation of the children wrongfully retained."

The defence remains difficult to establish, not least, because the court will take into consideration the possibility that the child's views have been strongly influenced by the adults with whom they are currently living. The

42 See fn 23 above.

43 Article 12 of the Convention on the Rights of the Child.

44 Freeman "In the Best Interests of Internationally Abducted Children: Plural, Singular, Neither or Both?" May 2002 IFL 78-79.

45 Article $13(\mathrm{~b})$ of the Convention provides a possible defence, or an exception to the mandatory return of a child when the child "objects to being returned and has attained an age and degree of maturity at which it is appropriate to take account of its views". See also s 278(3) of the Children's Act, which provides that the court must afford the affected child an opportunity to object and, having regard to the child's age and maturity, give due weight to any such objection.

46 Ibid.

47 Tribe Constitutional Law 2ed (1988) 666.

48 South African Roads Board v Johannesburg City Council 1991 (4) SA 13 par 13B-C.

49 See fn 32 at 526. 
court will accord little if any weight if it believes that the child was under the undue influence of the abductor parent. Hence, the application of this provision is not mandatory.

\section{Human rights issue}

An application for the return of the child may be refused if the enforcement of a custody decision would "not be permitted by the fundamental principles of the requested state relating to the protection of human rights and fundamental freedoms". ${ }^{50}$

\section{CHALLENGES WITH THE HAGUE CONVENTION}

There are risk factors if the child is abducted to a foreign country, especially if the country is not a party to the Hague Convention on International Child Abduction. This is due to the fact, that securing the prompt return of the child requires two-way cooperation between Contracting States. ${ }^{51}$ Lack of cooperation would result in the ineffectiveness of the return remedy.

Although the Hague Convention does not apply in circumstances where a child is abducted to a state that is not a party to the Hague Convention, ${ }^{52}$ it is, however, possible to pursue the custody case through a normal civil procedural order. Article 29 of the Hague Convention provides that the Convention shall not preclude application directly to the judicial or administrative authorities of a contracting state, "whether or not under the provisions of the Convention". ${ }^{33}$ The order must declare that the removal or the retention of the child in a foreign country is wrongful, and it is a breach of the rights of the left behind parent, which were obtained in terms of a court order in the area where the child was habitually a resident. ${ }^{54}$ In order to be successful with the application, the applicant must be able to show that custody rights were exercised at the time of the removal or retention of the minor child. ${ }^{55}$

The effectiveness of the above statute seems to be limited, especially considering the need for the applicant to establish the wrongfulness of removing or retaining the child in a foreign country. There must, therefore, be an existing law that makes parental abduction in violation of a custody order a criminal offence, and this offence must be punishable.

The difficulties involved are that the process itself may prove to be quite expensive; further, the court system and the language used in that particular state may be unfamiliar. There are also barriers relating to travelling to another country to pick up the child once that child has been located and recovered by law enforcing officials. The challenge is that the Children's Act

\footnotetext{
Article 20 of the Hague Convention.

Dyer "The Internationalization of Family Law" 1997 U.C Davis LR 625

52 Estin "Families across Borders: The Hague Children's Conventions and The International Family Law in the United States" 201062 Florida LR 52.

53 Convention on the Rights of the Child.

54 Article 3(2) of the Hague Convention.

55 Ibid.
} 
does not make provision for the travel costs, where it is ordered that the child has to be returned to its habitual resident. It is therefore presumed that the travel costs may be ordered to be paid by the abducting parent. It, therefore, becomes difficult for some parents to afford plane tickets or to get their passports issued quickly.

It may be argued that legal aid is available for those who need assistance or unable to pay legal fees, however, very few have access to this kind of assistance. It is therefore important that precise and workable requirements can be enshrined for use by the courts in accordance with relevant circumstances. The author therefore recommends that there must be an expansion of legal aid programs for parents in child abduction cases.

Another major problem in child abduction cases is the location of the child and the offending parent, and returning them to the appropriate parent having lawful custody of the child. The Hague application must be filed as soon as possible after abduction or wrongful removal has taken place. The time for when an application must be filed is on a date that is less than one year after the prosecuting parent has learned that the child was in fact abducted. If the application is filed more than one year, such an application may be dismissed as a threshold matter because it was not timely filed. ${ }^{56}$

\section{THE NOTION OF THE BEST INTERESTS OF THE CHILD IN ABDUCTION CASES}

By virtue of the constitutional provision for the best interests of the child in all matters involving children, it would be argued that the discretion of the courts in terms of section 28(2) has been corroded. A constitutional duty to give paramountcy to the best interests of the child has now been imposed on them. Every matter should be decided on its own facts, with the interests of the child in each case being the decisive factor.

Even in cases where the country is not a member state, it is presumed that the courts will decide the case solely on the best interests of the child concerned. The paramountcy principle of the best interests of the child should be at the forefront. However, if it can be established that there is "grave risk that his or her return would expose the child to physical or psychological harm or otherwise place the child in an intolerable situation", the court may refuse to return the child.

In the case of $W S v L S,^{57}$ two South African citizens travelled to the United Kingdom shortly after their marriage, because the applicant acquired a visa to work in the United Kingdom for four years. Both their children aged one year, seven months, and a four-month old were born in the United Kingdom. When the parties had marital problems, the respondent and their two children left for Cape Town for a two-month holiday.

While in South Africa, after the expiry of two months, the respondent informed the applicant of her intention not to return to the United Kingdom. She further informed the applicant that she had instituted divorce

\footnotetext{
Article 12 of the Hague Convention.

57 Supra.
} 
proceedings in South Africa. The applicant then served the Hague Convention application on the respondent for the return of unlawfully removed or retained children. The respondent requested the court to refuse such an application in terms of Article 13 (b) of the Hague Convention. The court did not determine a grave risk of harm to the children; however, it supported the tender age doctrine and the maternal preference. The court held that it is not in the best interests of the very young children to be parted from their mother, and further that it was unthinkable to separate very young children from each other. ${ }^{58}$

In $P \vee P,{ }^{59}$ Chetty $\mathrm{J}$ said determining the child's best interests:

"[i]n any particular case involves the High Court making a value judgment, based on its findings of fact, in the exercise of its inherent jurisdiction as the upper guardian of the minor children".

The court's duty is to reach a decision that will ultimately be based on what it believes to be in the best interests of the child. Unfortunately, there are many judges who do not adopt the child-centred model, they adopt an adult-oriented approach in interpreting the Hague Convention and as such fail to sufficiently take into account the rights and interests of the child. ${ }^{60}$ Therefore, the question of whether the child is settled or not should be looked at from the perspective of the child and not that of the parent, this will be in line with what the child-centred approach requires. that:

Justice Sachs when delivering judgment in the case of $S v M^{61}$ pointed out

"A truly principled child-centred approach requires a close and individualized examination of the precise real-life situation of the particular child involved. To apply a pre-determined formula for the sake of certainty, irrespective of the circumstances, would, in fact, be contrary to the best interests of the child concerned."

In Central Authority $\mathrm{v} \mathrm{H}^{62}$ three and a half years had elapsed from the time of the wrongful retention. The delay was partly attributed to the South African Central authority, as such, the application took two to three years to be finalised. During the period, the child was residing in the requested country. However, the child was returned to the Netherlands almost three and a half years of its removal. The court, unfortunately, did not examine the best interests of the individual child.

In the case of $L S \vee A T^{63}$ it was held that a court considering an application under the Hague Convention must:

"place in the balance the desirability, in the interests of the child, of the appropriate court retaining its jurisdiction... and the likelihood of undermining

\footnotetext{
See fn 56 above par 116A-C.

60 Schuz "The Hague Child Abduction Convention and the United Nations Convention on the Rights of the Child" 2002 12(2) Transnational Law and Contemporary Problems 393452. 
the best interests of the child by ordering her or his return to the jurisdiction of that court".

Courts have consistently held that decisions about child custody should be based on the best interests of the individual child. ${ }^{64}$ It is generally accepted that removing a child suddenly from its home, without reaching any sort of agreement with the parent left behind about contact or about the child's future living arrangements, is not in the best interests of the child. Abducted children can suffer physical and emotional harm and find themselves isolated from the environment to which they have become accustomed and from a parent, family members, friends, and school. Abducted children are unfortunately deprived a stable and safe home life following their parents' divorce.

In the case of Sonderup $v$ Tondelli, ${ }^{65}$ the court also found that the Hague Convention is carefully tailored to achieve its ends with consideration given to the best interests of the child. This is because the Hague Convention gives a requested state discretion to refuse to return a child under the "grave risk" exception in Article 13b of the Hague Convention.

In the case of $C \vee C,{ }^{66}$ the court concluded that the Hague Convention did not require English courts to consider the welfare of the children as paramount, but should determine whether there was a grave risk of harm from an order to return the child. However, this approach received criticism in Pennello $v$ Pennello ${ }^{67}$ where the court held that the view that the child's best interests are not paramount is inconsistent with the preamble. The courts should consider the best interests of the child as the decisive factor in every matter concerning the child.

\section{HOW CAN WE PROTECT CHILDREN FROM PARENTAL ABDUCTION?}

There is an old adage that says, "an ounce of prevention is worth a pound of cure" 68 which the Hague Convention seems to ignore. It seems as if treatment attracts greater priority while prevention seems to be overlooked, and rationally, this appears to make little sense. The aim of the Hague Convention is clearly not to deter an act of parental abduction but to establish procedures to ensure the prompt return of the child, which is the foremost concern once abduction has occurred. ${ }^{69}$

\footnotetext{
64 Article 3(1) of the Convention on the Rights of the Child, which provides that "In all concerning children, whether undertaken by public or private social welfare institutions, courts of law, administrative authorities or legislative bodies, the best interests of the child shall be a primary consideration."

652001 (1) SA 1171 (CC).

661989 (2) All ER $465(\mathrm{HL})$.

2004 (1) All SA 32 (SCA).

68 An axiom by Ben Franklin.

69 Hillebard "Parental Kidnapping and the Tort of Custodial Interference: Not in a Child's Best Interest" 199225 Indiana LR 902.
} 
Therefore, the best way to handle parental child abductions is to prevent it before it occurs. ${ }^{70}$ Preventative measures may include the following:

- Custody orders must have very specific requirements spelling out contact and removal from the child's habitual residence. The implications for contempt of these orders must also be specified.

- Parents may also request assistance in working out the arrangements for a custody order by going to a mediator who will help them to come up with their own agreement that the judge can incorporate into a court order.

- Copies of court orders must be given to the child's school, day care facilities, and agencies that issue out passports requesting those agencies to deny issuance or replacement of the child's passport without the custodial parent's permission, or without the certified written authorisation of either parents or the court. ${ }^{71}$

- The other parent must not be denied access to the child; otherwise, the denying parent may be accused of interfering with the other parent's rights by taking, hiding or keeping the child from them. However, impositions of restrictions on the other parent's freedom to be with the child or supervised visitation may be necessary, especially where there is a threat of child abduction.

\section{CONCLUSION}

The Hague Convention's objectives are clearly well intended $;^{72}$ however, they are flawed in that there is a greater need to come up with measures to prevent parental child abduction. Having the laws that implement the Hague Convention and actions toward enforcing court orders pursuant to Hague applications might be a step in the right direction; however, this is not the most effective way of protecting children's rights and deterring potential abductors.

Much research has been conducted to determine the effects of parental abductions on children. Cross-border abductions clearly have harmful effects on children, therefore in order to protect children from such harmful effects, and to promote the best interests of the child, the Hague Convention must provide a procedure designed to prevent the removal of children from the state of their habitual residence.

In the United States of America, especially California, parental abduction is a crime; perpetrators are frequently arrested and prosecuted. This was included in their statutes in order to deter an act of parental abduction. It would thus, be foolish to ignore or dismiss the lessons from a country like the United States of America as we share historical links with this legal system.

It is critical that preventative measures are put in place to prevent parental child abduction, and such measures will aid in preventing costly litigation

70 Freeman Parental Child Abduction: The Long-Term Effects (2014) 37.

71 Foreman Kidnapped: Child-Snatching, A World Problem (1980).

72 See Article 1 of the Hague Convention, which makes provision for the maximum protection for the rights of every individual child who has been abducted. 
associated with Hague Convention applications. As it has already been pointed out, where parental abduction occurs, it can result in technically challenging and costly investigations or litigation.

South Africa must, therefore, embark on law reform processes relevant to parental abduction. The South African Law Reform Commission must investigate the possibility of drafting legislation regarding the protection of parental child abduction. Unless measures are put in place to protect parental child abduction, the guarantee is that children will continually experience more confusion, hardship and significant risk of harm. 